\title{
Electrochemical Corrosion of Ti6Al4V, Ti and AISI 316L SS After Immersed in Concentrated Simulated Body Fluid ${ }^{1}$
}

\author{
A. Buyuksagis \\ Afyon Kocatepe University, Science and Literature Faculty, Afyonkarahisar, Turkey \\ e-mail: ayselbuyuksagis@hotmail.com,absagis@aku.edu.tr \\ Received April 6, 2015
}

\begin{abstract}
The biomimetic method is used to obtain hydroxyapatite (HAP) coatings on Ti6Al4V, Ti and AISI 316L SS substrates. These substrates with different pretreatment surface operations $\left(\mathrm{HNO}_{3}\right.$, anodic polarization, base-acid) were immersed in concentrated simulated body fluids (SBF) for different days at physiologic conditions of $37^{\circ} \mathrm{C}$, initial $\mathrm{pH}$ of 7.4. Then the corrosion behaviours of substrates after immersion in concentrated SBF were examined by electrochemical methods in Ringer's and $0.9 \mathrm{wt} \% \mathrm{NaCl}$ solutions at a temperature of $37^{\circ} \mathrm{C}$. Ions concentrations and $\mathrm{pH}$ analyses were carried out after incubation in concentrated SBF. After immersion in SBF for different days, the surface morphology remains almost unchanged and no apatite formation is observed. Corrosion currents of substrates increased after immersion. Ions concentrations and $\mathrm{pH}$ values were shown variability according to soaking time and pretreatment surface operations.
\end{abstract}

DOI: $10.1134 / \mathrm{S} 2070205116040067$

Keywords:Biomimetic, SBF, corrosion, pretreatment surface operations, hydroxyapatite

The repair or replacement of damaged hard tissues such as bone is a major clinical problem around the world. Titanium, Ti6Al4V alloy and AISI 316L SS are widely used as orthopedic and dental implant materials due to their low elastic modulus, good biocompatibility and corrosion durability. However, bone does not bond directly to these materials as they get encapsulated by fibrous tissue after implantation, which isolates them from the surrounding bone [1-13]. In order to enhance the bone-bonding ability, titanium, its alloys and AISI 316L SS are often coated with hydroxyapatite (HAP). HAP is known for its biocompatible, bioactive (i.e. ability of forming a direct chemical bond with surrounding tissues), osteoconductive, non-toxic, noninflammatory, non-immunogenic properties $[6,7,10$, 11, 13-20]. Many different techniques have been used application of HAP coatings onto metal substrates; biomimetic, dip coating, thermal spraying and pulsed laser deposition, electrolytic deposition, electrochemical deposition, a sol-gel method, sputter coating, using wet chemical precipitation methods, hydrothermal treatments, electrodeposition and (micro)emulsion techniques. Most of them were conducted to obtain HAP nanoparticles having ideal stoichiometry and high crystallinity [5, 21-24].

Recent researchs have shown that the biomimetic process is one of the most promising techniques for producing a bioactive coating at ambient temperature

\footnotetext{
${ }^{1}$ The article is published in the original.
}

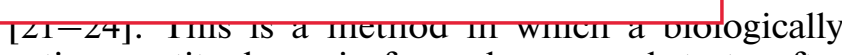
active apatite layer is formed on a substrate after immersion in an artificially prepared supersaturated calcium and phosphate solution known as SBF [25]. The use more concentrated SBF solution allows the deposition of an homogeneous Ca-P coating within 24 $\mathrm{h}$ and a few hours [1, 2, 4, 26-28].

This paper presents, the biomimetic method is used to obtain hydroxyapatite (HAP) coatings on Ti6Al4V, Ti and AISI 316L SS substrates. The solutions are prepared concentrated simulated body fluid $(\mathrm{SBF})$ as $1.5 \times \mathrm{SBF}$ and $3.0 \mathrm{xSBF}$. Additionally, three different pretreatment surface operations $\left(\mathrm{HNO}_{3}\right.$, anodic polarization, base-acid) are applied to the substrates. Substrates soaked in $3.0 \mathrm{xSBF}$ and $1.5 \mathrm{xSBF}$ solution different immersion periods of $1,2,3,4,5,6$, 7 days. Corrosion behavior of substrates after immersion were examined in the Ringer's and 0.9 wt. \% $\mathrm{NaCl}$ solutions at a temperature of $37^{\circ} \mathrm{C}$. Ions concentrations and $\mathrm{pH}$ analyses were carried out after incubation in concentrated simulated body fluid

\section{EXPERIMENTAL}

\subsection{The Preparation of the Substrates}

Surface properties of the substrates play a major role in the development of biomimetic HAP coatings and their corrosion resistance. Commercially available Ti6Al4V alloy, pure Ti and AISI 316L SS substrates are used. They are polished with $\mathrm{SiC}$ paper at different grades $(240,400,600,800,1000$ and 1200$)$, washed by 
Special constitutions of SBF, blood plasma, 1.5xSBF and 3.0xSBF

\begin{tabular}{l|c|c|c|c|c|c|c|c}
\multicolumn{1}{c|}{ Ions } & $\mathrm{Na}^{+}$ & $\mathrm{K}^{+}$ & $\mathrm{Ca}^{2+}$ & $\mathrm{Mg}^{2+}$ & $\mathrm{Cl}^{-}$ & $\mathrm{HCO}_{3}^{-}$ & $\mathrm{HPO}_{4}^{2-}$ & $\mathrm{S} \mathrm{O}_{4}^{2-}$ \\
\hline SBF concentration $\left(\mathrm{mmol} \mathrm{dm}^{-3}\right)$ & 142.00 & 5.00 & 2.50 & 1.50 & 147.80 & 4.20 & 1.00 & 0.50 \\
Blood plasma concentration $\left(\mathrm{mmol} \mathrm{dm}^{-3}\right)$ & 142.00 & 5.00 & 2.50 & 1.50 & 103.80 & 27.00 & 1.00 & 0.50 \\
$1.5 \mathrm{xSBF}$ concentration $\left(\mathrm{mmol} \mathrm{dm}^{-3}\right)$ & 213.00 & 7.50 & 3.75 & 2.25 & 221.70 & 6.30 & 1.50 & 0.75 \\
$3.0 \times$ xBF concentration $\left(\mathrm{mmol} \mathrm{dm}^{-3}\right)$ & 426.00 & 15.00 & 7.50 & 4.50 & 443.40 & 12.60 & 3.00 & 1.50 \\
\hline
\end{tabular}

using Bandelin ultrasonic bath for 15 minutes in order acetone, alcohol and rinsed with bidistilled water at $30^{\circ} \mathrm{C}$ and finally dried in an oven at $40^{\circ} \mathrm{C}$. Thus, they are made ready for pretreatment surface operations (PTSO).

\subsection{Pretreatment Surface Operations of Substrates (PTSO)}

Overall the experiments, the chemicals used for the study were reagents grade (Merck) precisely weighted. Three pre-treatments are applied in order to accelerate the coating process, including acid treatment $\left(\mathrm{HNO}_{3}\right)$, acid treatment- alkali treatment (BA), and anodic treatment (anodic).

These are summarized as follows:

a) Acid-base (BA) PTSO: The substrates are immersed in $5 \mathrm{~mol} \mathrm{dm}^{-3} \mathrm{NaOH}$ solutions for 12 hours at $60^{\circ} \mathrm{C}$ and they are kept for 12 hours at $25^{\circ} \mathrm{C}$. Then, they are washed in the ultrasonic bath for 15 minutes by bidistilled water for two times and are dried oven at $40^{\circ} \mathrm{C}$ for one hour. After that substrates were kept in $1 \mathrm{~mol} \mathrm{dm}^{-3} \mathrm{HCl}$ at $60^{\circ} \mathrm{C}$ for 12 hours, and then 12 hours at $25^{\circ} \mathrm{C}$. Following the acid treatment, the substrates are rewashed in the ultrasonic bath for 15 minutes with bidistilled water for two times and are dried in the drying oven at $40^{\circ} \mathrm{C}$ for one hour $[1,4,5$, $10,19,23,24,28-34]$.

b) Anodic polarization PTSO: Anodic polarization is done in $1 \mathrm{~mol} \mathrm{dm}^{-3} \mathrm{HCI}$ aqueous solution. It is confirmed that optimum treatment time was 300 seconds in $1 \mathrm{~mol} \mathrm{dm}^{-3} \mathrm{HCl}$ aqueous solution and the potential value is determined as $5 \mathrm{~V}$.

c) $\mathrm{HNO}_{3}$ PTSO: Substrates were soaked for $20 \mathrm{~min}-$ utes in technical $\mathrm{HNO}_{3}$ and after the acid treatment, the substrates are washed with running bidistilled water and dried at $40^{\circ} \mathrm{C}$ for one hour. The substrates are cleaned in Bandelin ultrasonic bath for 15 minutes in order acetone, alcohol, and bidistilled water $30^{\circ} \mathrm{C}$. Then, substrates are dried at $40^{\circ} \mathrm{C}$ for one hour in the drying oven. Surface of substrates is made porous for HAP coating. Substrates are kept in desiccator after put in locked plastic bags [35-39].

\subsection{Experimental studies of biomimetic HAP coating}

HAP coating with biomimetic method is summarized as follows:

a) The ion concentration in SBF closely resembles the concentration of human blood plasma are prepared using Kokubo's formulation by dissolving reagent-grade of $\mathrm{CaCl}_{2}, \mathrm{~K}_{2} \mathrm{HPO}_{4} \cdot 3 \mathrm{H}_{2} \mathrm{O}, \mathrm{KCl}, \mathrm{NaCl}$, $\mathrm{MgCl}_{2} \cdot \mathrm{H}_{2} \mathrm{O}, \mathrm{NaHCO}_{3}$ and $\mathrm{Na}_{2} \mathrm{SO}_{4}$ in bidistilled water. SBF solutions are prepared as $3.0 \mathrm{xSBF}$ and 1.5xSBF. Special constitutions of SBF, blood plasma, $1.5 \mathrm{xSBF}$ and 3.0xSBF $[1,35-38,40-42]$ are given on Table 1. BA, $\mathrm{HNO}_{3}$ and anodic PTSO are applied seperately to substrates. To increase ion concentration and to make easier the composition of the core apatite, solutions are prepared as $1.5 \mathrm{xSBF}$ and $3.0 \mathrm{xSBF}$ and buffering at physiological $\mathrm{pH}$ of 7.4 with $0.1 \mathrm{~mol} \mathrm{dm}^{-3}$ tris (hydroxymethyl) aminomethane (TRIS) and $0.1 \mathrm{~mol} \mathrm{dm}^{-3}$ hydrochloric acid $(\mathrm{HCl})$ at $37^{\circ} \mathrm{C}$ [44] TRIS was used to provide stability of solution [1, 33, 43-50]. Results described in the literature [43] where SBF is shown to be easily contaminated by bacteria even after short time exposure unless the experiments are conducted under strict aseptic conditions its concentration in the solution. Furthermore, these bacteria can be a health risk for the human [51]. In order to prevent bacterial reproduction $\mathrm{NaN}_{3}$ was added to the solution as it will be $20 \mathrm{mg} \mathrm{dm}^{-3}[52,53]$.

Prepared concentrated SBF solutions stored in glass bottles and kept in a refrigerator. The SBF shall be used within 30 days after preparation [34]. They could be equilibrated at the testing temperature and carefully mixed just before use [54].

b) 3 samples of substrates are put in each glass bottle. Surface areas of Ti and Ti6Al4V substrates were $2.0096 \mathrm{~cm}^{2}$ and totally $75 \mathrm{~cm}^{3}$ concentrated SBF solution is added [33, 35]. For that surface area of AISI $316 \mathrm{~L}$ SS substrates were $0.785 \mathrm{~cm}^{2}$, totally $40 \mathrm{~cm}^{3}$ concentrated SBF is added [35, 44, 55, 56].

c) Glass bottles are put into the the shaking water bath and shaking speed is arranged as $80 \mathrm{rpm}$, bath temperature $37^{\circ} \mathrm{C}$ [57]. The substrates are soaked in concentrated SBF for various periods of from 1 to 7 days before they are taken out for testing and analysis. After the biomimetic HAP coating in concentrated SBF solutions, substrates are washed kindly with bidistilled water, kept in the drying oven at $40^{\circ} \mathrm{C}$ for 


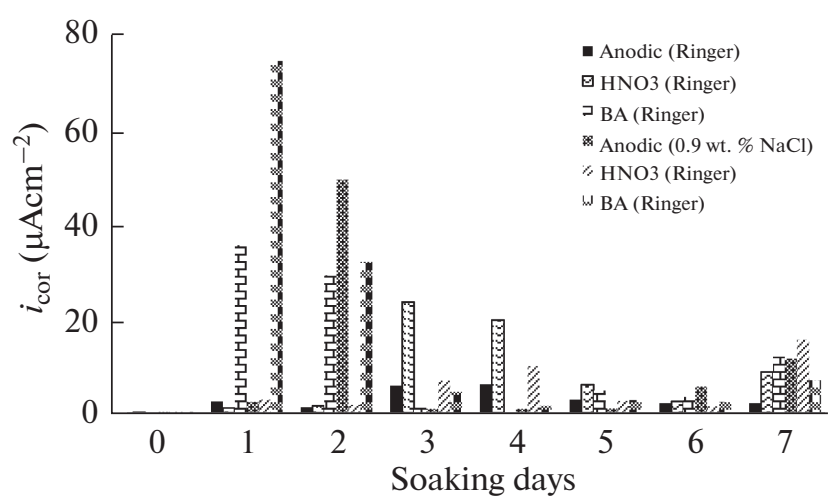

Fig. 1. Corrosion current densities of Ti6Al4V substrates after immersed in 3.0xSBF for different soaking days.

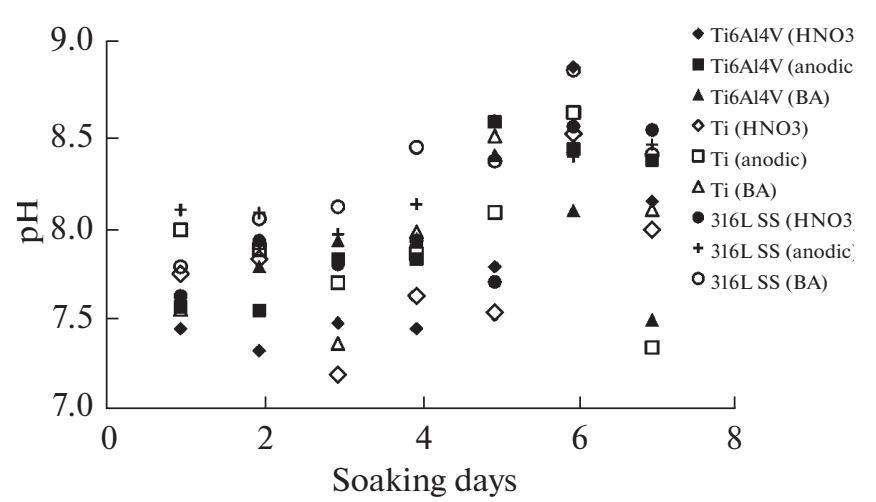

Fig. 2. pH values of substrates after immersed in 3.0xSBF for different soaking days.

time periods $E_{\text {corr }}$ values of $\mathrm{HNO}_{3}$ and anodic PTSO Ti6Al4V substrates in Ringer's solution (immersion in $3 \mathrm{xSBF}$ ) shifted to more positive potentials. Hydroxyapatite coating with biomimetic method in $3 \mathrm{xSBF}$ solution did not occur on the surface of Ti6Al4V substrates. Corrosion current densities of Ti6Al4V substrates are the level of $\mu \mathrm{A}$ although $3 \mathrm{xSBF}$ solution (about 3 times concentrated than body fluid) is very intensive. Corrosion resistance of Ti6Al4V are very low, $\beta_{\mathrm{a}}$ and $\beta_{\mathrm{c}}$ values can be changeable according to solution type ( $0.9 \mathrm{wt} \% \mathrm{NaCl}$ and Ringer's solution) and soaking times. Krupa et al. [46] study have shown that after the oxidation of titanium, the corrosion resistance increases. After long-term exposures, calcium phosphates were found on the sample surface, and their amount was bigger on the oxidised surfaces. As a result of corrosion experiments of Ti6Al4V substrates are carried out in Ringer's solution $\left(\mathrm{HNO}_{3}\right.$ PTSO and immersed in $3 \mathrm{xSBF}$ ), corrosion current density is increased with increasing duration time until $3^{\text {rd }}$ days. Ti6Al4V alloy in $0.9 \mathrm{wt} \% \mathrm{NaCl}$ solution shows same behavior despite being a few exceptions. Corrosion currents in 0.9 wt $\% \mathrm{NaCl}$ are less than Ringer's solution in $3^{\text {rd }}, 4^{\text {th }}, 5^{\text {th }}$ days of soaking. $\mathrm{pH}$ values of substrates after immersed in 3.0xSBF for different soaking days is given Fig. 2 Considering $\mathrm{pH}$ change for $\mathrm{HNO}_{3}$ PTSO Ti6Al4V substrates (Fig. 2), $\mathrm{pH}$ is increased as the immersion time increases in concentrated SBF solution. This shows that apatite nucleation starts on surface consist of oxides and hydroxides. $\mathrm{Ca}^{2+}$ ions increased until $5^{\text {th }}$ holding days (except $4^{\text {th }}$ holding days) then they decreased (Fig. 3).

This indicates that $\mathrm{Ca}^{2+}$ ions are solved in a SBF solution [23]. $\mathrm{CaO}$ phase is formed $\mathrm{Ca}^{2+}$ in hydroxyapatite structure more readily soluble and $\mathrm{Ca}^{2+}$ concentrations were varied anodic and BA PTSO Ti6Al4V substrates. When the concentration of $\mathrm{PO}_{4}^{3-}$ analyzed is decreased till $5^{\text {th }}$ immersion days and then it is increased. This can be interpreted $\mathrm{PO}_{4}^{3-}$ contributed to 

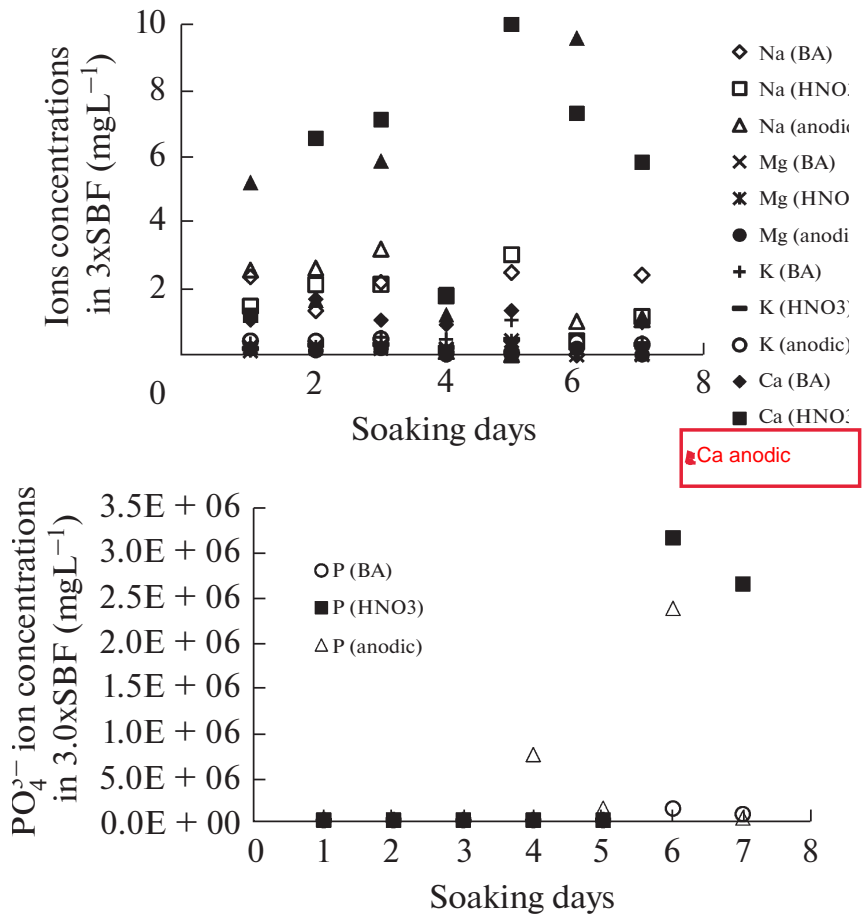

Fig. 3. Ions concentrations after immersed in 3.0xSBF for different soaking days and Ti6Al4V.

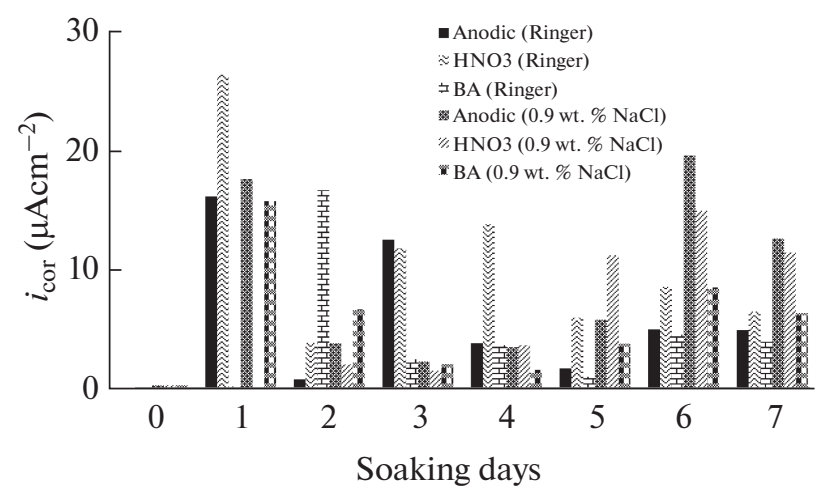

Fig. 4. Corrosion current densities of Ti substrates after immersed in 3.0xSBF for different soaking days.

the formation of apatite on the surface of Ti6Al4V substrates and then $5^{\text {th }}$ soaking days apatite rapidly dissolved in SBF solution. Consequently corrosion experiments of Ti6Al4V substrates in Ringer's solution (immersed in 3xSBF and anodic PTSO), corrosion current density is increased until $4^{\text {th }}$ days of exposure to concentrated SBF solution (excepts $2^{\text {nd }}$ days). This shows that corrosion products occurred on the of the Ti6Al4V substrate cover of surface, therefore the corrosion current densities are decreased. Corrosion experiments of the Ti6Al4V substrate in $0.9 \mathrm{wt} \% \mathrm{NaCl}$ solutions (anodic PTSO and soaked in $3 \mathrm{xSBF}$ ), corrosion current densities are increased until $4^{\text {th }}$ day of immersion (except $2^{\text {nd }}$ days) then corrosion current densities increased. $\mathrm{TiO}_{2}$ can be occurred on the surface of Ti6Al4V substrates by using anodic PTSO with potentiostat this product will help to passivation of surface. $\mathrm{pH}$ is increased as the immersion time increased (Fig. 2). $\mathrm{Ca}^{2+}$ ions concentration shows variability according to conditions. Increase of $\mathrm{Ca}^{2+}$ ions in solution according to ICP-OES analysis shows that $\mathrm{Ca}^{2+}$ ions soluble from the surface of substrat (Fig. 3). It can be interpreted decrease of $\mathrm{Ca}^{2+}$ ions in solution supported apatite formation. The same thing can be said of phosphate ions.

When we considering corrosion experiments of Ti6Al4V in Ringer's solution (soaked in 3xSBF and BA PTSO substrates). Although corrosion current density increases in the first days of immersion and then decreases gradually again in the next $4^{\text {th }}$ days. Corrosion current densities of Ti6Al4V after $5^{\text {th }}$ and $6^{\text {th }}$ soaking in $3 \times$ SBF have not increased notably and $7^{\text {th }}$ days significantly increased.

The formation and growing of apatite on $\mathrm{Ti}$ implant surface support by alkali PTSO and then heat treatment process [60]. A porous layer after alkaline PTSO is occurred. During drying process come cracks comprise. Cracks are caused by the thermal coefficients are due to the difference between the metal and hydroxyapatite [60]. The cracks are sourced by the diffusion reaction between the coated surface and SBF. Some micro cracks is by virtue of diffusion of ions from SBF to coating surface. The ions solubility in hydroxyapatite coating are affected from phase crystallinity porosity and thick of metal substrate [23]. $\mathrm{pH}$ changes of substrates (BA PTSO and immersed in $3 \mathrm{xSBF}$ ) increased until $5^{\text {th }}$ soaking days (Fig. 2) then decreased $\mathrm{pH}$ increase is supported the apatite formation [5].

The $\mathrm{NaOH}$ pre-treated titanium metal forms apatite in a biological environment through the following mechanism. The metal releases sodium ions from the surface amorphous sodium titanate layer into the surrounding fluid through an ion exchange process and with the hydronium ions present in the surrounding fluid leads to form Ti-OH groups on its surface. The $\mathrm{Ti}-\mathrm{OH}$ groups induce apatite nucleation, and the released sodium ions accelerate the apatite formation by increasing the $\mathrm{pH}$ of the fluid.

$$
\begin{gathered}
\mathrm{TiO}_{2}+\mathrm{OH}^{-} \rightarrow \mathrm{HTiO}_{3}, \\
\mathrm{Ti}+3 \mathrm{OH}^{-} \rightarrow \mathrm{Ti}(\mathrm{OH})^{3 / 4}+4 \mathrm{e}, \\
\mathrm{Ti}(\mathrm{OH})^{3 / 4}+\mathrm{e} \rightarrow \mathrm{TiO}_{2} \mathrm{H}_{2} \mathrm{O}+0.5 \mathrm{H}_{2} .
\end{gathered}
$$

Corrosion current densities of $\mathrm{Ti}$ substrates after immersed in $3.0 \mathrm{xSBF}$ for different soaking days is given Fig. 4.

When Fig. 4 is noted that corrosion current density of pure $\mathrm{Ti}$ in $0.9 \mathrm{wt} \% \mathrm{NaCl}$ solution (soaked in $3 \mathrm{xSBF}$ and $\mathrm{HNO}_{3} \mathrm{PTSO}$ ) is very small. Percent inhibition 
value is $99 \%$. The corrosion experiments in Ringer's solution (soaked in 3.0xSBF and $\mathrm{HNO}_{3} \mathrm{PTSO}$ ) corrosion current densities show variability depending on immersion time. In this instance surface of Ti consisted of oxides and hydroxides. Growed out of oxide and hydroxides covered the surface of $\mathrm{Ti}$ caused decrease of corrosion current density. Acid etching of titanium generates a $\mathrm{TiH}_{2}$ layer and subsequent $\mathrm{NaOH}$ treatment induces the growth of a sodium titanate layer. Immediately after exposure of pre-treated titanium to SBF, calcium and hydronium ions substitute sodium that is leached from the sodium titanate layer. The formation of $\mathrm{OH}^{-}$groups at the surface leads to $\mathrm{pH}$ increase and thus to an increase of the ionic activity and of the super saturation of the SBF solution with respect to carbonated apatite in the region near the surface. As a result a calcium phosphate nucleates on the calcium titanate layer [61].

In addition, after the soaking experiments, sintering process is performed in a muffle furnace. Sintering process is carried out $850^{\circ} \mathrm{C}$ for one hour by use normal air. Titanium at high temperature is very sensitive to $\mathrm{H}_{2}, \mathrm{O}_{2}$ and $\mathrm{N}_{2}$ gases and occur titanium oxide and titanium nitride oxidized by these gases. Titanium hydride rapidly develops upper $250^{\circ} \mathrm{C}$. Absorption of $\mathrm{O}_{2}, \mathrm{~N}_{2}$ and $\mathrm{H}_{2}$ leads to fragility at high temperatures [62]. When short duration time experiments (1-7 days) are analyzed in $3 \mathrm{xSBF}$ solution, corrosion currents are seen higher (excepts some exception). Likewise, $\mathrm{pH}$ values (Fig. 2) are variable of corrosion current densities. Naturally or anodically formed oxide on $\mathrm{Ti}$, which essentially consists of Ti dioxide $\left(\mathrm{TiO}_{2}\right)$, effectively protects the metal from rapid dissolution in the harsh body environment. Furthermore, the oxide film enables Ti to exhibit bioactivity in body fluid by providing a site for the deposition of calcium and phosphate compounds and thus induce ionic exchange with apatite from bone tissue [6]. It is important that the anodized surfaces, where the oxide layer was intentionally increased, interacted more actively with modified SBF. Anodized surfaces have more oxygen, a higher chemical potential (e.g., $\left.\mathrm{OH}^{-}\right)$, and $\mathrm{Ca}^{2+}$ and $\mathrm{P}^{3-}$ ions incorporated during anodic oxidation [63].

In Figs. 5 and 6 summarized different biomimetic conditions used to produce apatite coating, also from the first day until $7^{\text {th }}$ days of immersion, corrosion current densities of hydroxyapatite coated 316 L stainless steel are increased and polarization resistance of them are decreased. $i_{\text {corr }}$ values of $316 \mathrm{~L} \mathrm{SS}$ are considerably higher than Ti6Al4V alloy and Ti substrates. According to Nagayama and Kawamura [64]; the film layer on the iron are as follows: They founded that outer layer $\mathrm{Fe}_{2} \mathrm{O}_{3}$ formed in the active zone consist of $\mathrm{Fe}_{3} \mathrm{O}_{4}$ on the iron surface.

Studies on retrieved implants showed that more than $90 \%$ of the failure of 316L SS-implants is due to localized electrochemical cells resulting in pitting

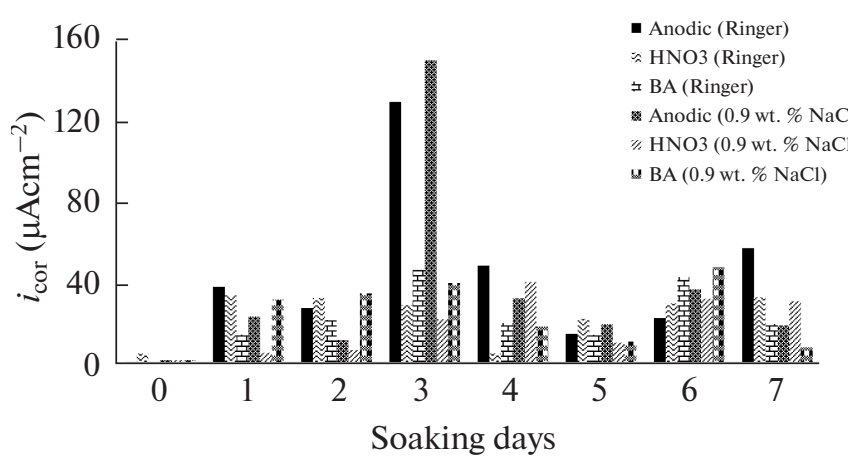

Fig. 5. Corrosion current densities of AISI 316L SS substrates after immersed in 3.0xSBF for different soaking days.

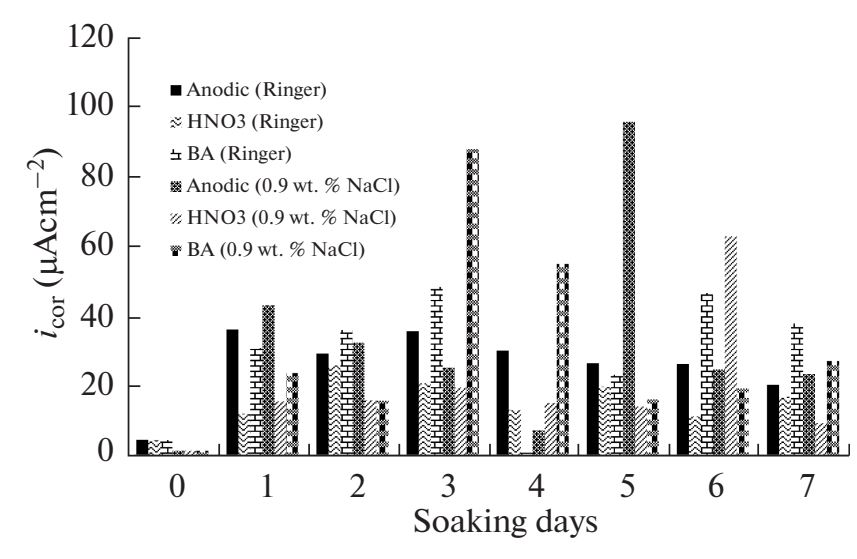

Fig. 6. Corrosion current densities of AISI 316L SS substrates after immersed in $1.5 \mathrm{xSBF}$ for different soaking days.

attack, or crevice corrosion at the interface between a plate and a locking screw. The increased electrochemical activity by increasing the deformation degree might be related to the increased martensite content due to deformation. The martensite phase could act as an anode in an electrochemical cell and is thereby prone to selective dissolution. Chloride ions are adsorbed preferentially on martensite locations and then react with the surface film. This leads to destruction of the surface film and delays its restoration. Generally, corrosion resistance of stainless steels is achieved by dissolving a sufficient amount of chromium in iron to produce a coherent, adherent, insulating and regenerating chromium oxide protective film $\left(\mathrm{Cr}_{2} \mathrm{O}_{3}\right)$ on the surface. This passive film of chromium oxide formed in air at room temperature is only about $1-2 \mathrm{~nm}$. Pitting corrosion is the result of the local destruction of the passive film and subsequent corrosion of the steel underneath this layer. The pit formation is influenced by many factors such as martensite content, dislocation density and internal stresses [65]. A. Barbucci et al. [66] have related the pit initiation to the passive film stability, which is influenced by cold deformation. The increased number of pits by increased cold work suggests a much higher 


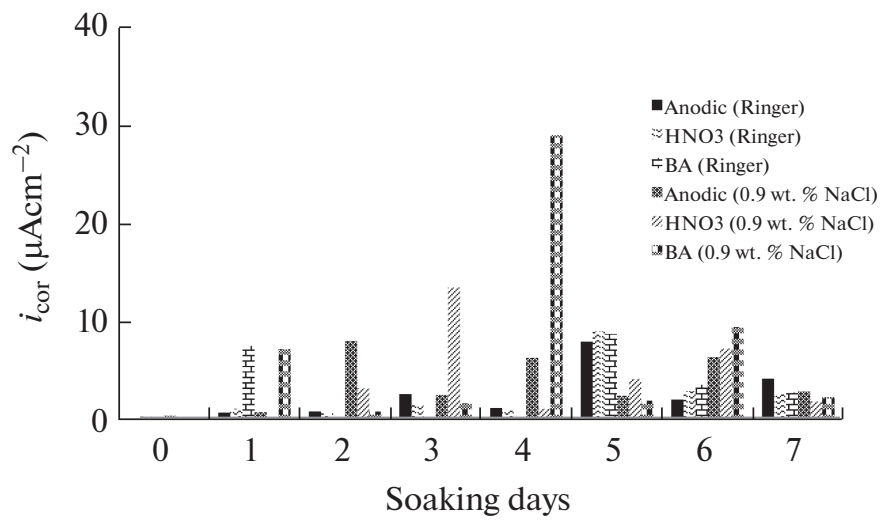

Fig. 7. Corrosion current densities of Ti6Al4V substrates after immersed in $1.5 x S B F$ for different soaking days.

defective oxide film in deformed material. Practically said that $\mathrm{Cl}^{-}$ions often cause pitting corrosion of metals. The mechanism of pitting corrosion by $\mathrm{Cl}^{-}$ions is not fully explained. The best explanation for pitting corrosion has been to give the free acide, $\mathrm{Cl}^{-}$formed $\mathrm{HCl}$ to connection water.

Figure 7 presents, corrosion current densities of Ti6Al4V substrates in Ringer's solution (BA PTSO and soaked in $1.5 \times \mathrm{xBF}$ ) are decreased and polarization resistance values are increased $2^{\text {nd }}, 3^{\text {rd }}$, $4^{\text {th }}$ immersed days. Percent inhibition values are calculated for the first day duration time is $66 \%$, for $2^{\text {nd }}$ and $4^{\text {th }}$ days duration time are $90 \%$, for $3^{\text {rd }}$ days duration time is $91 \%$. When metals treated in $\mathrm{NaOH}$ are soaked in SBF, the alkali ion in the alkali titanate layer exchanges with the hydronium ion in the fluid, to increase the ionic activity product of the apatite in the fluid by increasing $\mathrm{pH}$. Simultaneously, hydrated titania is formed on their surfaces, and induces the apatite [7]. There aren't any linear change as a result of after corrosion experiments in Ringer's solution (immersed in $1.5 x \mathrm{XBF}$ and $\mathrm{HNO}_{3} \mathrm{PTSO}$ ). After corrosion experiments in Ringer's solution (soaked $1.5 \times \mathrm{XBF}$ and $\mathrm{HNO}_{3}$ PTSO) corrosion current density decreased

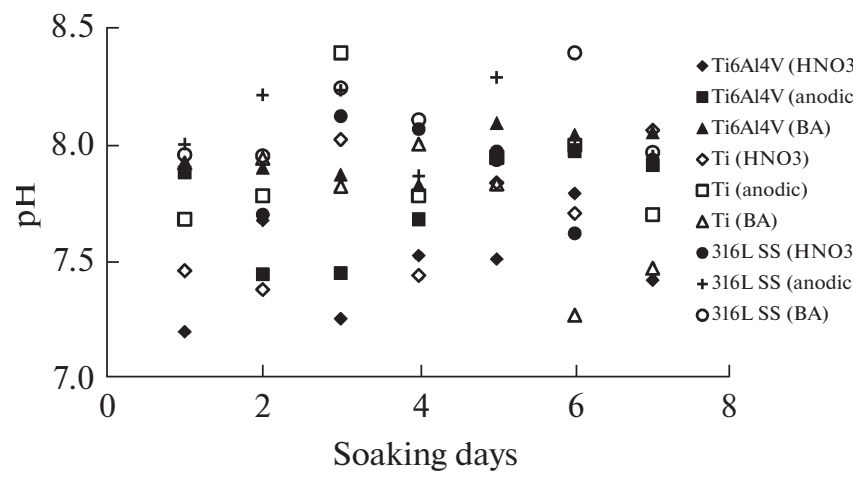

Fig. 8. $\mathrm{pH}$ values of substrates after immersed in $1.5 \mathrm{xSBF}$ for different soaking days. increasing soaking time till $2^{\text {nd }}$ days and increased $3^{\text {rd }}$ and $5^{\text {th }}$ duration time days. Lu et al. [67] proposed that the increased surface roughness of the Ti specimen by etching with mixed acids led to good adherence between $\mathrm{Ca}-\mathrm{P}$ coatings and substrates.

Hereby corrosion experiments in 0.9 wt $\% \mathrm{NaCl}$ solution (immersed in $1.5 \times \mathrm{xBF}$ and $\mathrm{HNO}_{3} \mathrm{PTSO}$ ), corrosion current density of Ti6Al4V substrates increased until $3^{\text {rd }}$ days of immersion and then variability show increase and decrease. When we look at $\mathrm{pH}$ changes (Fig. 8), $\mathrm{HNO}_{3}$ PTSO Ti6Al4V substrates), they are seen that the formation of oxide on Ti6Al4V surface ions quantity of $\mathrm{Ca}^{2+}$ ions (Fig. 9 and $\mathrm{HNO}_{3}$ PTSO) are decreased (except $5^{\text {th }}$ days duration time). Decreasing $\mathrm{Ca}^{2+}$ ions in solutions show that $\mathrm{Ca}^{2+}$ ions deposited on the substrates for formed apatite. In solution analysis phosphate quantity is decreased. This show that formation of apatite less than $3 \mathrm{xSBF}$ avoided and a uniform surface coverage of apatite on the Ti6Al4V substrates was obtained according to the following equation [5].

$$
10 \mathrm{Ca}^{2+}+6 \mathrm{PO}_{4}^{3-} \cdot 2 \mathrm{OH} \leftrightarrow \mathrm{Ca}_{10}\left(\mathrm{PO}_{4}\right)_{6}(\mathrm{OH})_{2}
$$

Cationic species, i.e. $\mathrm{Ca}^{2+}$ and $\mathrm{Mg}^{2+}$ are favorably attracted onto the $\mathrm{TiO}_{2}$ passive layer covering Ti6Al4V plates. Titanium substrate is believed to be negatively charged at physiological $\mathrm{pH}$, whereas results show evidences for chemical affinities between $\mathrm{Ti}$ and $\mathrm{HPO}_{4}{ }^{2-}$ but rarely $\mathrm{Ti}$ and $\mathrm{Ca}^{2+}$ [2]. The negatively charged surfaces are always favorable for the heterogeneous nucleation of HAP in a supersaturated solution called "simulated body fluid" (SBF) or Kokubo solution, whereas the nucleation is inhibited on positive surfaces. The accepted interpretation is that the accumulation of $\mathrm{Ca}^{2+}$ ions due to the electrostatic attraction increases the super saturation near the negative surfaces, and as a result, the initial nucleation is preferentially triggered [34].

The presence of $\mathrm{Na}^{+}, \mathrm{HPO}_{4}^{2-}, \mathrm{HCO}_{3}^{-}, \mathrm{Ca}^{2+}, \mathrm{Cl}^{-}$in the aqueous media of $\mathrm{SBF}$ maintained at $7.4 \mathrm{pH}$ 

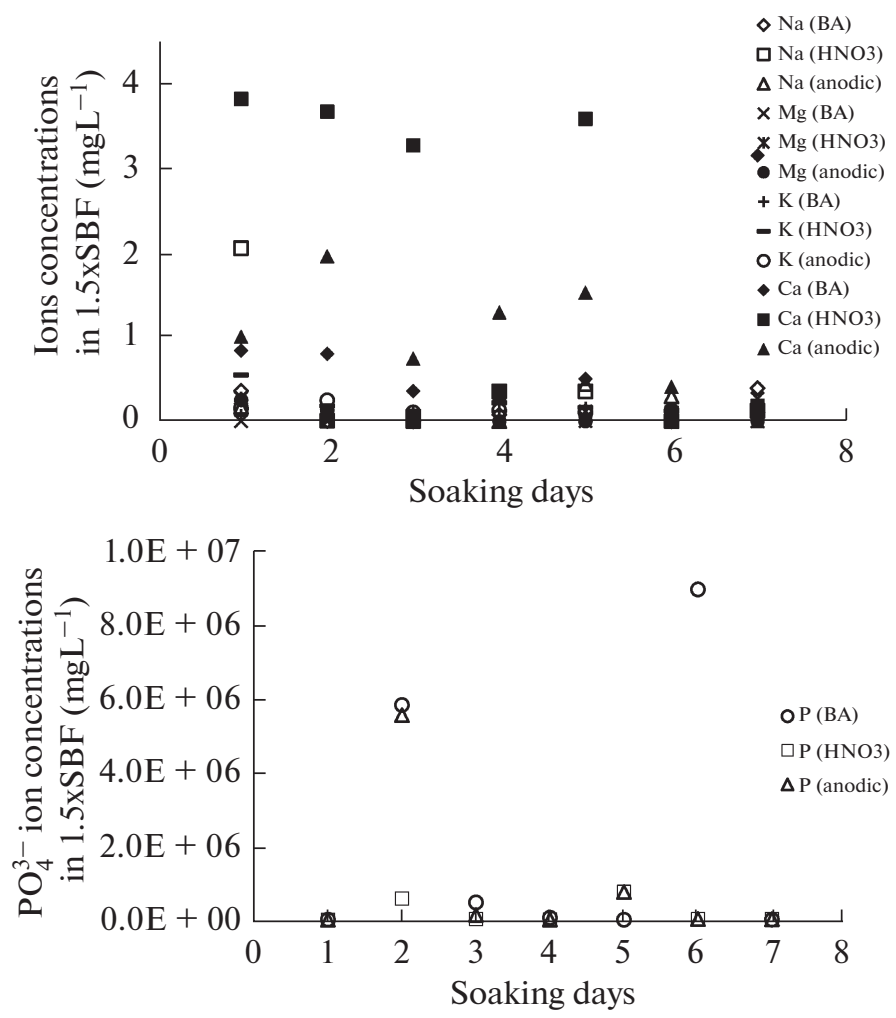

Fig. 9. Ions concentrations after immersed in $1.5 \mathrm{xSBF}$ for different soaking days and Ti6Al4V.

results in formation of $\mathrm{NaCl}$; increased ionic strength leads to an increase in $\mathrm{pH}$ of solution [69]. The asdeposited thin films soaked in SBF for 4 weeks did not show any notable amount of apatite particles on their surfaces [70].

Corrosion current densities of Ti6Al4V substrates in Ringer's solution (soaked in $1.5 \times \mathrm{XBF}$ and $\mathrm{BA}$ PTSO) are very low $2^{\text {nd }}, 3^{\text {rd }}$ and $4^{\text {th }}$ days of exposure to $1.5 \mathrm{xSBF}$ solution, Ti6Al4V alloy shows the passivity properties. Then corrosion increased breakdown of passive film. Corrosion current densities of Ti6Al4V substrates in $0.9 \mathrm{wt} \% \mathrm{NaCl}$ solution (soaked in $1.5 \mathrm{xSBF}$ and BA PTSO) is decreased until $3^{\text {rd }}$ and $4^{\text {th }}$ days of immersion as regional corrosion current is increased by breaking the film. Corrosion current is reduced again to repair film itself. $\mathrm{Ca}^{2+}$ ions values showed significantly variability. There aren't $\mathrm{Ca}^{2+}$ ions in solution $6^{\text {th }}$ days of immersion. After $\mathrm{NaOH}$-treatment of the Ti6Al4V substrate, due to surface passivation $\mathrm{TiO}_{2}$ is formed. The alkali treatment produces negatively charged $\mathrm{Ti}-\mathrm{O}$-groups interacting with positively charged $\mathrm{Ca}^{2+}$ ions, which in turn attract phosphate ions from the precursor solution to form an initial calcium-phosphate layer [5, 11, 24, 25, 29, 34, 71].

Figure 10 offers, the corrosion current densities are increased, polarization resistance are decreased. Corrosion current densities compared in 0.9 wt. $\% \mathrm{NaCl}$ and Ringer's solution, corrosion current densities of anodic PTSO Ti substrates are lower than corrosion currents of BA PTSO and $\mathrm{HNO}_{3}$ PTSO Ti substrates $\left(1^{\text {st }}, 2^{\text {nd }}, 3^{\text {rd }}\right.$ and $5^{\text {th }}$ days of immersion $)$. Corrosion experiments of $\mathrm{Ti}$ substrates $\left(\mathrm{HNO}_{3} \mathrm{PTSO}\right.$ and immersed in $1.5 \mathrm{xSBF}$ ) corrosion current densities increase with increasing duration time till $6^{\text {th }}$ days. The chemical treatment with an acidic $\mathrm{HNO}_{3}$ aqueous solution $(\mathrm{pH}=0.7)$ results in an anatase-type $\mathrm{TiO}_{2}$ film of very low crystallinity $\left(\mathrm{TiO}_{2}\right.$ gel) formed on the

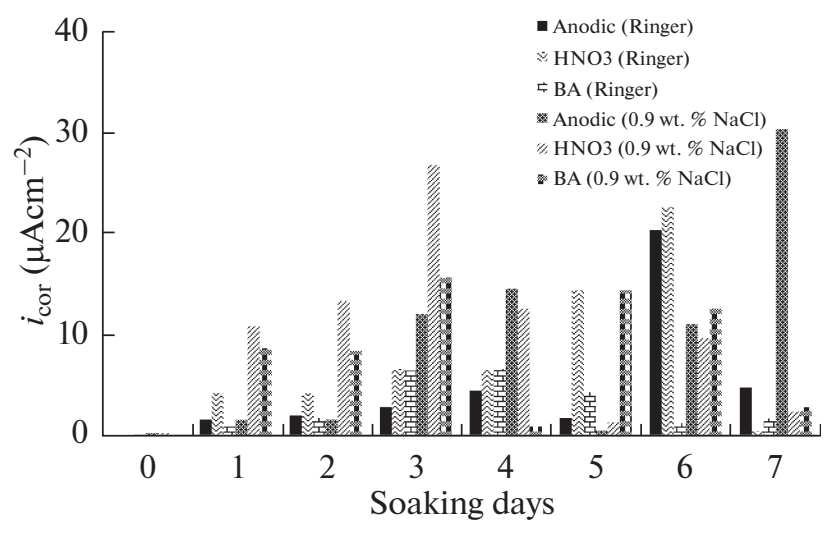

Fig. 10. Corrosion current densities of Ti substrates after immersed in $1.5 x$ SBF for different soaking days. 
Ti surface. The Ti-OH groups reportedly act as nucleation sites for HAP on $\mathrm{TiO}_{2}$. As pointed out in, the Ti-OH groups react with hydroxyl ions in the SBF, $(\mathrm{pH}=7.4)$, leading to a negatively charged surface with functional $\mathrm{Ti}-\mathrm{O}$-groups. The latter attract from the SBF positively charged $\mathrm{Ca}^{2+}$ ions which in turn attract negatively charged $\mathrm{PO}_{4}^{3-}$ ions from the solution. Subsequently, a calcium-phosphate layer is formed on the $\mathrm{TiO}_{2}$ surface. Thus, soaking in $\mathrm{H}_{2} \mathrm{O}_{2}$ results in the formation of Ti-OH groups owing to the interaction of Ti cations from the oxide layer with $\mathrm{OH}^{-}$groups in the aqueous medium. The $\mathrm{Ti}-\mathrm{OH}$ groups may be either acidic or basic, depending on the $\mathrm{pH}$ of the solution, hence, higher $\mathrm{pH}$ values provide better conditions for the HA nucleation and growth.

Once apatite nuclei are formed, they grow spontaneously by calcium and phosphorous ions from the surrounding solution and this can be further enhanced if the sodium titanate on its surface is converted into anatase $\mathrm{Ti}[5]$.

Corrosion current densities of Ti substrates (soaked in $1.5 \mathrm{xSBF}$ and $\mathrm{HNO}_{3}$ PTSO) are increasing with increased duration time till $3^{\text {th }}$ days of immersion. At this stage oxides and hydroxides formed on Ti surface. Formed these oxides and hydroxides covered the $\mathrm{Ti}$ surface and corrosion is reduced.

Corrosion currents of Ti substrates in Ringer's solution (immersed in 1.5xSBF and anodic PTSO) are increased with increasing soaking time until $4^{\text {th }}$ days. At this stage oxides and hydroxides formed on Ti surface. Corrosion current is decreased until $5^{\text {th }}$ and $7^{\text {th }}$ days of immersion, corrosion current increased $6^{\text {th }}$ days of immersion. Similar behaviour is observed in 0.9 wt $\% \mathrm{NaCl}$ solution. Corrosion currents of $\mathrm{Ti}$ substrates in 0.9 wt $\% \mathrm{NaCl}$ solution (soaked in 1.5xSBF and BA PTSO) changeability demonstrated. Etching in either alkaline or acid solution is often used to obtain $\mathrm{Ti}-\mathrm{OH}$ bonds and porous structures to induce HAP deposition [6]. It is suggested that a porous network of the titanium surface arising after the $\mathrm{NaOH}$ pretreatment favors the nucleation of calcium phosphates [11].

First of all corrosion current densities decreased then resulting oxides and hydroxides surface closed. Corrosion currents increased due to aggressive chloride ions in the Ringer's and $0.9 \mathrm{wt} \% \mathrm{NaCl}$ solution. The measured $\mathrm{pH}$ values (Fig. 8, BA PTSO Ti) is typically considered to be 7.28 and above. The cathodic reaction in neutral and alkaline solutions are in the form of reduction of water and oxygen. For this reason at these $\mathrm{pH}$ 's formed oxides and hydroxides on the surface. Aforementioned explains increasing and then decreasing the corrosion is due to oxides and hydroxides formation.

It should also be emphasized that the modification of SBF had reproducible and effective results on biomimetic deposition. A limitation of biomimetic depo- sition is the slow rate of $\mathrm{CaP}$ deposition, with a lack of reproducibility of its effects due to the arbitrary SBF composition [54].

\section{CONCLUSIONS}

- Apatite cannot form on the surface of substrates after concentrated SBF soaking tests.

- $\mathrm{pH}$ is increased as the immersion time increases in concentrated SBF solutions

- Increase of $\mathrm{Ca}^{2+}$ and $\mathrm{PO}_{4}^{3-}$ ions in concentrated $\mathrm{SBF}$ solution shows that ions soluble from the surface of substrates

- Corrosion current densities increased with duration soaking times.

\section{ACKNOWLEDGMENTS}

The author gratefully acknowledge the Scientific and Technical Research Council of Turkey (TUBITAK) for the financial support with the Grant Number of 107M563.

\section{REFERENCES}

1. Bharati, S., Sinha, M., and Basu, D., Bull. Mater. Sci., 2005, vol. 28, p. 617.

2. Barrere, F., van Blitterswijk, C., de Groot, K., and Layrolle, P., Biomaterials, 2002, vol. 23, p. 2211.

3. Barriere, F., Layrolle, P., van Blitterswijk, C., et al., Bone, 1999, vol. 25, p. 107S.

4. Bigi, A., Boanini, E., Bracci Facchini, A., et al., Biomaterials, 2005, vol. 26, p. 4085.

5. Faure, J., Balamurugan, A., Benhayoune, H., et al., Mater. Sci. Eng.: C, 2009, vol. 29, p. 1252.

6. Anawati Tanigawa, H., Asoh, H., Ohno, T., et al., Corros. Sci., 2013, vol. 70, p. 212.

7. Janković, A., Eraković, S., Mitrić, M., et al., J. Alloys Compd., 2014, vol. 624, p. 148.

8. Mohseni, E., Zalnezhad, E., and Bushroa, A., Int. J. Adhes. Adhes., 2014, vol. 48, p. 238.

9. Pasinli, A., Yuksel, M., Celik, E., et al., Acta Biomater., 2010, vol. 6, p. 2282.

10. Stoch, A., Jastrzebski, W., Brozek, A., et al., J. Mol. Struct., 2000, vol. 555, p. 375.

11. Yanovska, A., Kuznetsov, V., Stanislavov, A., et al., Surf. Coat. Technol., 2011, vol. 205, p. 5324.

12. Yoon Il-Kyu, Hwang Ji-Young, Jang Won-Cheoul, et al., Appl. Surf. Sci., 2014, vol. 301, p. 401.

13. Sutha, S., Kavitha, K., Karunakaran, G., and Rajendran, V., Mater. Sci. Eng.: C, 2013, vol. 33, p. 4046.

14. Swetha, M., Sahithi, K., Moorthi, A., et al., Int. J. Biol. Macromol., 2010, vol. 47, p. 1.

15. Cai, Q., Feng, Q., Liu, H., and Yang, X., Mater. Lett., 2013, vol. 91, p. 275.

16. McLeod, K., Kumar, S., Dutta, N.K., et al., Appl. Surf. Sci., 2010, vol. 256, p. 7178 . 
17. Minh, D.P., Nzihou, A., and Sharrock, P., Mater. Res. Bull., 2014, vol. 60, p. 292.

18. Mohseni, E., Zalnezhad, E., and Bushroa, A.R., Int. J. Adhes. Adhes., 2014, vol. 48, p. 238.

19. Sadjadi, M.S., Meskinfam, M., Sadeghi, B., et al., Mater. Chem. Phys., 2010, vol. 124, p. 217.

20. Štulajterova, R. and Medvecky, L., Colloids Surf., A, 2008, vol. 316, p. 104.

21. Hashizume, M., Nagasawa, Y., Suzuki, T., et al., Colloids Surf., B, 2011, vol. 84, p. 545.

22. Gao, F., Xu, C., Hu, H., et al., Mater. Lett., 2015, vol. 138, p. 25.

23. Gu, Y.W., Khor, K.A., and Cheang, P., Biomaterials, 2003, vol. 24, p. 1603.

24. Chu, C.L., Pu, Y.P., Yin, L.H., et al., Mater. Lett., 2006, vol. 60 , p. 3002.

25. Zhang, Q. and Leng, Y., Biomaterials, 2005, vol. 26, p. 3853.

26. Costa, D.O., Allo, B.A., Klassen, R., et al., Langmuir, 2012, vol. 28, p. 3871.

27. Čolović, B., Jokanović, V., Jokanović, B., and Jović, N., Ceram. Int., 2014, vol. 40, p. 6949.

28. Habibovic, P., Barrère, F., van Blitterswijk, C.A., et al., J. Am. Ceram. Soc., 2002, vol. 85, p. 517.

29. Chen, X., Li, Y., Hodgson, P.D., and Wen, C., Mater. Sci. Eng.: C, 2009, vol. 29, p. 165.

30. Gu, Y.W., Tay, B.Y., Lim, C.S., and Yong, M.S., Biomaterials, 2005, vol. 26, p. 6916.

31. Jalota, S., Bhaduri, S.B., and Tas, A.C., Mater. Sci. Eng.: C, 2008, vol. 28, p. 129.

32. Holzwarth, J.M. and Ma, P.X., Biomaterials, 2011, vol. 32, p. 9622.

33. Tas, A.C., J. Eur. Ceram. Soc., 2000, vol. 20, p. 2389.

34. Kokubo, T. and Takadama, H., Biomaterials, 2006, vol. 27 , p. 2907.

35. Jonasova, L., Muüller, F.A., Helebrant, A., et al., Biomaterials, 2004, vol. 25, p. 1187.

36. Khor, K.A., Li, H., Cheang, P., and Boey, S.Y., Biomaterials, 2003, vol. 24, p. 723.

37. Saiz, E., Goldman, M., Gomez-Vega, J.M., et al., Biomaterials, 2002, vol. 23, p. 3749.

38. Ning, C.Q. and Zhou, Y., Biomaterials, 2002, vol. 23, p. 2909.

39. Büyüksağis, A., Çiftci, N., Ergün, Y., and Kayalı, Y., Prot. Met. Phys. Chem. Surf., 2011, vol. 47, p. 670.

40. Lin, C.M. and Yen, S.K., Mater. Sci. Eng.: C, 2006, vol. 26, p. 54.

41. Wei, D. and Zhou, Y., Ceram. Int., 2009, vol. 35, p. 2343.

42. Forsgren, J., Svahn, F., Jarmar, T., and Engqvist, H., Acta Biomater, 2007, vol. 3, p. 980.

43. Ciobanu, G., Carja, G., and Ciobanu, O., Surf. Coat. Technol., 2008, vol. 202, p. 2467.

44. Lluch, A.V., Ferrer, G.G., and Pradas, M.M., Colloids Surf., B, 2009, vol. 70, p. 218.
45. Kannan, S., Balamurugan, A., and Rajeswari, S., Electrochim. Acta, 2004, vol. 49, p. 2395.

46. Krupa, D., Baszkiewicz, J., Sobczak, J.W., et al., J. Mater. Process. Technol., 2003, vol. 144, p. 158.

47. Balamurugan, A., Balossier, G., Kannan, S., et al., Ceram. Int., 2007, vol. 33, p. 605.

48. Ding, S.J., Huang, T.H., and Kao, C.T., Surf. Coat. Technol., 2003, vol. 165, p. 248.

49. Rigo, E.C.S., Boschi, A.O., Yoshimoto, M., et al., Mater. Sci. Eng.: C, 2004, vol. 24, p. 647.

50. Jalota, S., Bhaduri, S., and Tas, A., Mater. Sci. Eng.: C, 2007, vol. 27, p. 432.

51. Müller, L. and Müller, F., Acta Biomater., 2006, vol. 2, p. 181.

52. Xiao, X.F., Tian, T., Liu, R.F., and She, H., Mater. Chem. Phys., 2007, vol. 106, p. 27.

53. Shi, Y., Downes, M., Xie, W., et al., Genes Dev., 2001, vol. 15 , p. 1140.

54. Bohner, M. and Lemaitre, J., Biomaterials, 2009, vol. 30, p. 2175.

55. Oliveira, A.L., Costa, S.A., Sousa, R.A., and Reis, R.L., Acta Biomater., 2009, vol. 5, p. 1626.

56. Sánchez-Salcedo, S., Balas, F., Izquierdo-Barba, I., and Vallet-Regi, M., Acta Biomater., 2009, vol. 5, p. 2738.

57. Li, F., Feng, Q.L., Cui, F.Z., et al., Surf. Coat. Technol., 2002, vol. 154, p. 88.

58. Chou, Y.F., Chiou, W.A., Xu, Y., et al., Biomaterials, 2004, vol. 25, p. 5323.

59. Uchida, M., Kim, H.M., Kokubo, T., et al., J. Biomed. Mater. Res., Part A, 2003, vol. 64, p. 164.

60. Escada, A.L.A., Rodrigues, D., and Machado, J.P.B., Surf. Coat. Technol., 2010, vol. 205, p. 383.

61. Müller, F.A., Müller, L., Caillard, D., and Conforto, E., J. Cryst. Growth, 2007, vol. 304, p. 464.

62. Şengil, İ.A., Korozyon, İ.T.Ü. Sakarya Mühendislik Fakültesi Matbaass, 1992, vol. 1501, p. 494.

63. Sul, Y.T., Johansson, C.B., Petronis, S., et al., Biomaterials, 2002, vol. 23, p. 491.

64. Nagayama, M. and Kawamura, S., Electrochim. Acta, 1967, vol. 12, p. 1109.

65. Mhaede, M., Ahmed, A., Wollmann, M., and Wagner, L., Mater. Sci. Eng.: C, 2015, vol. 50, p. 24.

66. Barbucci, A., Delucchi, M., Panizza, M., et al., J. Alloys Compd., 2001, vols. 317-318, p. 607.

67. Lu, X., Zhao, Z., and Leng, Y., Mater. Sci. Eng.: C, 2007 , vol. 27, p. 70.

68. Kokubo, T., Thermochim. Acta, 1996, vols. 280-281, p. 479.

69. Karanjai, M., Sundaresan, R., Mohan, T.R.R., and Kashyap, B.P., Mater. Sci. Eng.: C, 2008, vol. 28, p. 1401.

70. Amin, M.S., Randeniya, L.K., Bendavid, A., et al., Diamond Relat. Mater., 2012, vol. 21, p. 42.

71. Chi, M.H., Tsou, H.K., Chung, C.J., and He, J.L., Thin Solid Films, 2013, vol. 549, p. 98. 